\title{
Balneola alkaliphila sp. nov., a marine bacterium isolated from the Mediterranean Sea
}

\author{
Laurent Urios, ${ }^{1}$ Laurent Intertaglia, ${ }^{1}$ Françoise Lesongeur ${ }^{2}$ \\ and Philippe Lebaron ${ }^{1}$ \\ 1Observatoire Océanologique, Laboratoire d'Océanographie Biologique de Banyuls, Université \\ Pierre et Marie Curie (Paris VI), Institut National des Sciences de I'Univers (INSU), CNRS UMR \\ 7621, BP44, 66651 Banyuls-sur-Mer Cedex, France \\ ${ }^{2}$ Laboratoire de Microbiologie des Environnements Extrêmes, UMR 6197, IFREMER, Centre de \\ Brest, BP 70, 29280 Plouzané, France
}

Correspondence

Philippe Lebaron

lebaron@obs-banyuls.fr
Stoecker et al. (2006) have provided molecular evidence that the genus Crenothrix belongs to the order Methylococcales. Consequently, other genera originally assigned to the family Crenotrichaceae within the order Sphingobacteriales are currently considered Sphingobacteriales genera incertae sedis, including the genera Rhodothermus (Alfredsson et al., 1988; Sako et al., 1996) and Salinibacter (Antón et al., 2002), which include species that exhibit extremophilic characteristics. Rhodothermus strains are thermophilic and their optimal growth temperatures are between 60 and $80{ }^{\circ} \mathrm{C}$. Salinibacter strains are extreme halophiles that require at least $150 \mathrm{~g}$ salt $1^{-1}$ for growth. Recently, a new genus that was phylogenetically related to Rhodothermus and Salinibacter was described and named Balneola (Urios et al., 2006). This genus was defined by a single species, Balneola vulgaris, which was isolated from a seawater sample from the bay of Banyuls-sur-Mer (France) and which does not exhibit extremophilic characteristics. Optimal growth of B. vulgaris DSM $17893^{\mathrm{T}}$ was found to occur at $\mathrm{pH} 8.0$ and $30{ }^{\circ} \mathrm{C}$ and with $20 \mathrm{~g} \mathrm{NaCll}^{-1}$. Therefore, B. vulgaris did not exhibit any of the extreme features found in Rhodothermus and Salinibacter species. Here we describe a novel strain that was isolated from seawater in the same area as B. vulgaris. The strain presented characteristics that allowed the proposition of a novel species of the genus Balneola.

The GenBank/EMBL/DDBJ accession number for the 16S rRNA gene sequence of strain CM41_14b ${ }^{\top}$ is EU008564.

Graphs showing the effects of temperature, salinity and $\mathrm{pH}$ on the growth of strain CM41_14b $\mathrm{b}^{\top}$ are available as a supplementary figure with the online version of this paper.
Samples were collected in February 2004 in the bay of Banyuls-sur-Mer $\left(42^{\circ} 29^{\prime} \mathrm{N}^{\circ} 08^{\prime} \mathrm{E}\right)$ by submerging a sterile bottle and opening it at a depth of $3 \mathrm{~m}$. Subsamples were spread onto marine agar plates (MA 2216; Difco) and incubated at $25{ }^{\circ} \mathrm{C}$ for 2 weeks. Colonies were picked and purified after at least three subcultures. Among these colonies, an isolate that formed pale-orange colonies was obtained and designated strain CM41_14b $\mathrm{b}^{\mathrm{T}}$.

Microscopic observations (Olympus AX70) showed that cells of strain CM41_14b ${ }^{\mathrm{T}}$ were non-motile rods, approximately $2.6 \pm 0.1 \mu \mathrm{m}$ long and $0.7 \pm 0.05 \mu \mathrm{m}$ wide. The Ryu $\mathrm{KOH}$ reaction (Powers, 1995) led to immediate cell lysis that was confirmed by phase-contrast microscopy (Olympus AX70). This positive reaction indicated that the cells were Gram-negative.

Strain CM41_14b $\mathrm{b}^{\mathrm{T}}$ was grown in marine broth medium (MB 2216; Difco). To determine the salinity range for growth, MB 2216 was prepared according to the composition provided by the manufacturer, with the appropriate $\mathrm{NaCl}$ concentration. To determine the $\mathrm{pH}$ range for growth, MES, PIPES, AMPSO or MOPS (Sigma) was added to MB 2216 to reach the required $\mathrm{pH}$. Cultures were incubated at $30{ }^{\circ} \mathrm{C}$ under aerobic conditions. The methods used for the determination of growth parameters were as reported by Wery et al. (2001b). Growth was observed at $15-37{ }^{\circ} \mathrm{C}$, with optimum growth occurring at $25{ }^{\circ} \mathrm{C}$ (see Supplementary Fig. S1a, available in IJSEM Online). Growth rates were 10fold lower at 15 and $44{ }^{\circ} \mathrm{C}$, compared with the optimal growth rate at $25{ }^{\circ} \mathrm{C}$. Strain CM41_14b ${ }^{\mathrm{T}}$ grew at $\mathrm{NaCl}$ concentrations ranging from 10 to $80 \mathrm{~g} \mathrm{l}^{-1}$; an optimum 
concentration for growth could be defined at $30 \mathrm{~g} \mathrm{l}^{-1}$, but growth rates at 20 and $40 \mathrm{~g} \mathrm{l}^{-1}$ were only $10 \%$ lower than that at $30 \mathrm{~g} \mathrm{l}^{-1}$ (Supplementary Fig. S1b). Growth occurred at $\mathrm{pH}$ 6.0-10.0, with optimum growth between $\mathrm{pH} 8.0$ and 9.0. An approximately linear increase in growth rate was observed to occur between $\mathrm{pH} 6.0$ and 8.0 (Supplementary Fig. S1c). The ability of strain CM41_14b ${ }^{\mathrm{T}}$ to use different substrates was investigated using Biolog GN2 MicroPlates (Tang et al., 1998), according to the manufacturer's instructions. Positive reactions were observed for D-fructose, turanose, acetate, citrate, D-glucosaminic acid and inosine (Table 1). Weak positive reactions were observed for cellobiose, D-glucose, itaconate, glycyl L-aspartic acid and $\gamma$-aminobutyric acid (Table 1).

Enzymic activities were investigated using the API ZYM system (bioMérieux), according to the manufacturer's instructions. Alkaline phosphatase, leucine arylamidase, valine arylamidase and trypsin exhibited positive reactions, whereas reactions for chymotrypsin and acid phosphatase were weak. Catalase and oxidase tests were performed; strain CM41_14b $\mathrm{b}^{\mathrm{T}}$ was found to be catalase-positive and oxidase-negative. The presence of flexirubin pigments was investigated according to McCammon \& Bowman (2000); a negative reaction was observed.

Analysis of the fatty acid methyl esters was performed by the Identification Service of the Deutsche Sammling von Mikroorganismen und Zellkulturen (DSMZ, Braunschweig,
Germany). The fatty acid composition of strain CM41_14b was as follows: $15: 0$ iso $(45.2 \%), 15: 0$ iso $2-\mathrm{OH}(7.5 \%)$, $17: 1 \omega 8 c(1.8 \%), 15: 0(1.6 \%), 15: 1 \omega 6 c(4.3 \%), 13: 0$ iso (14.2\%), $17: 1 \omega 9 c$ iso $(9.7 \%), 15: 0$ anteiso $(3.3 \%), 15: 1$ iso $(2.7 \%), 17: 1 \omega 6 c(1.0 \%), 14: 0$ iso $(1.0 \%), 16: 0$ iso $(0.6 \%)$, $17: 0$ iso $(2.0 \%), 16: 0(0.6 \%), 15: 1 \omega 8 c(1.4 \%)$ and $16: 1 \omega 5 c$ $(1.2 \%)$. The major fatty acids were generally similar to those of $B$. vulgaris DSM $17893^{\mathrm{T}}$ (Urios et al., 2006); however, the amounts of 15:0 iso and 13:0 iso were twice those of $B$. vulgaris DSM $17893^{\mathrm{T}}$, the amount of $15: 1 \omega 6 \mathrm{c}$ was 2.5 -fold lower and $17: 1 \omega 8 \mathrm{c}$ and 15:0 were both 6-fold lower in strain CM41_14 $\mathrm{b}^{\mathrm{T}}$ compared with $B$. vulgaris DSM $17893^{\mathrm{T}}$. Fatty acids $17: 0$ and $15: 1$ iso were not detected in B. vulgaris DSM $17893^{\mathrm{T}}$.

Genomic DNA was extracted as described by Wery et al. (2001a). The G $+\mathrm{C}$ content was determined by thermal denaturation using the method of Marmur \& Doty (1962) and the conditions described by Raguénès et al. (1997). The $\mathrm{G}+\mathrm{C}$ content of the genomic DNA of strain CM41_14b was $39 \pm 1 \mathrm{~mol} \%$. The $16 \mathrm{~S}$ rRNA gene was amplified and sequenced as described by Agogué et al. (2005) and the sequence was analysed as described by Urios et al. (2006). Strain CM41_14b ${ }^{\mathrm{T}}$ was phylogenetically affiliated to the genus Balneola (Fig. 1). The closest relative was B. vulgaris DSM $17893^{\mathrm{T}}$, with a $16 \mathrm{~S}$ rRNA gene sequence similarity of $95 \%$.

Some characteristics of strain CM41_14b ${ }^{\mathrm{T}}$ differed from those of its closest relative: lower optimal temperature

Table 1. Characteristics that distinguish strain CM41_14b $\mathrm{b}^{\top}$ from its most closely related species, B. vulgaris

The two strains were isolated from seawater samples from the bay of Banyuls-sur-Mer, France. +, Positive; -, negative; $(+)$, weakly positive. Data for B. vulgaris are from Urios et al. (2006).

\begin{tabular}{|c|c|c|}
\hline Characteristic & B. vulgaris DSM $17893^{\mathrm{T}}$ & Strain CM41_14 $\mathrm{b}^{\mathrm{T}}$ \\
\hline Colony colour & Orange & Pale orange \\
\hline Motility & + & - \\
\hline Temperature range (optimum) for growth $\left({ }^{\circ} \mathrm{C}\right)$ & $10-40(30)$ & $15-37(25)$ \\
\hline Salinity range (optimum) for growth $\left(\mathrm{g} \mathrm{NaCl}^{-1}\right)$ & $0-50(20)$ & $10-80(30)$ \\
\hline \multicolumn{3}{|l|}{ Substrates utilized } \\
\hline Turanose & - & + \\
\hline D-Glucose & + & $(+)$ \\
\hline Cellobiose & - & $(+)$ \\
\hline Lactose & $(+)$ & - \\
\hline Maltose & + & - \\
\hline Itaconate & - & $(+)$ \\
\hline Inosine & - & + \\
\hline Glycyl L-aspartic acid & - & $(+)$ \\
\hline$\gamma$-Aminobutyric acid & - & $(+)$ \\
\hline
\end{tabular}




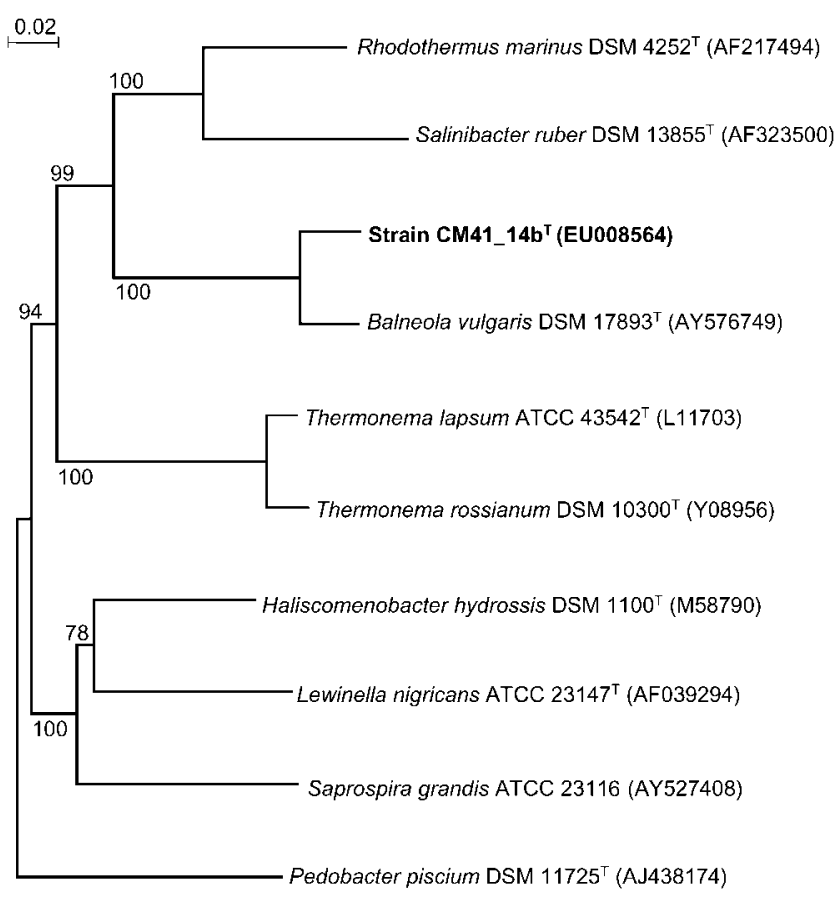

Fig. 1. Unrooted neighbour-joining phylogenetic tree (Kimura corrections), based on $16 \mathrm{~S}$ rRNA gene sequences, showing the position of strain CM41_14b $\mathrm{b}^{\mathrm{T}}$. The sequence of Pedobacter piscium DSM $11725^{\top}$ was used as the outgroup. GenBank accession numbers are given in parentheses. Bootstrap percentages (based on 1000 replications) are shown at branch points. Bar, 2 substitutions per 100 nucleotide positions.

$\left(5{ }^{\circ} \mathrm{C}\right)$, more-limited temperature range for growth, higher salinity range for growth (up to $30 \mathrm{~g} \mathrm{NaCl} \mathrm{l}^{-1}$ ) and a slightly higher $\mathrm{pH}$ optimum for growth of 8.0-9.0 (Table 1). Cells of strain CM41_14b $\mathrm{b}^{\mathrm{T}}$ were non-motile, unlike those of B. vulgaris DSM $17893^{\mathrm{T}}$. The $\mathrm{G}+\mathrm{C}$ content of strain CM41_14b $\mathrm{b}^{\mathrm{T}}$ was lower $(3 \mathrm{~mol} \%)$ than that of B. vulgaris DSM $17893^{\mathrm{T}}$.

Based on the phenotypic and genotypic differences between strain CM41_14b $\mathrm{b}^{\mathrm{T}}$ and its closest relative, we propose that strain CM41_14 $\mathrm{b}^{\mathrm{T}}$ represents a novel species of the genus Balneola. Because of the differences in $\mathrm{pH}$ range and optimum between B. vulgaris and strain CM41_14 $\mathrm{b}^{\mathrm{T}}$, the name Balneola alkaliphila sp. nov. is proposed.

\section{Description of Balneola alkaliphila sp. nov.}

Balneola alkaliphila (al.ka.li.phi'la. N.L. n. alkali alkali; Gr. adj. philos loving; N.L. fem. adj. alkaliphila loving alkaline conditions).

Forms pale-orange colonies on MA 2216. Cells are nonmotile rods. Growth occurs at $15-37{ }^{\circ} \mathrm{C}$ (optimum, $25{ }^{\circ} \mathrm{C}$ ), at $\mathrm{pH}$ 6.0-10.0 (optimum, 8.0-9.0) and at salinities of 10$80 \mathrm{~g} \mathrm{NaCl}^{-1}$ (optimum, $30 \mathrm{~g} \mathrm{NaCl} \mathrm{l}^{-1}$ ). Positive reactions with Biolog GN2 plates are obtained for D-fructose, turanose, acetate, citrate, D-glucosaminic acid and inosine. Positive reactions (API ZYM) are obtained for alkaline phosphatase, leucine arylamidase, valine arylamidase and trypsin. The DNA $\mathrm{G}+\mathrm{C}$ content of the type strain is $39 \mathrm{~mol} \%$.

The type strain, CM41_14b $\mathrm{b}^{\mathrm{T}} \quad\left(=\mathrm{DSM} \quad 19538^{\mathrm{T}}=\mathrm{CIP}\right.$ $109603^{\mathrm{T}}=\mathrm{OOB} 103^{\mathrm{T}}$ ), was isolated from a water column in the bay of Banyuls-sur-Mer.

\section{Acknowledgements}

This work was supported by the Equipe Mixte de Recherche linking the Université Pierre et Marie Curie and the Centre National de la Recherche Scientifique to the Pierre Fabre Laboratories and the EU project BASICS (EVK3-CT-2002-00018). The project was also carried out in the frame of the MarBEF Network of Excellence 'Marine Biodiversity and Ecosystem Functioning' which is funded in the Community's Sixth Framework Programme (contract no. GOCE-CT2003-505446). This publication is contribution number MPS-08016 of MarBEF. It was also partly funded by the French programme 'Biodiversité et Changement Global - project: development of a coastal microbial observatory' from the Institut Français de la Biodiversité (IFB-GICC, Paris, France).

\section{References}

Agogué, H., Casamayor, E. O., Bourrain, M., Obernosterer, I., Joux, F., Herndl, G. J. \& Lebaron, P. (2005). A survey on bacteria inhabiting the sea surface microlayer of coastal ecosystems. FEMS Microbiol Ecol 54, 269-280.

Alfredsson, G. A., Kristjansson, J. K., Hjörleifsdottir, S. \& Stetter, K. O. (1988). Rhodothermus marinus, gen. nov., sp. nov., a thermophilic, halophilic bacterium from submarine hot springs in Iceland. J Gen Microbiol 134, 299-306.

Antón, J., Oren, A., Benlloch, S., Rodríguez-Valera, R., Amann, R. \& Rosselló-Mora, R. (2002). Salinibacter ruber gen. nov., sp. nov., a novel, extremely halophilic member of the Bacteria from saltern crystallizer ponds. Int J Syst Evol Microbiol 52, 485-491.

Marmur, J. \& Doty, P. (1962). Determination of the base composition of deoxyribonucleic acid from its thermal denaturation temperature. J Mol Biol 5, 109-118.

McCammon, S. A. \& Bowman, J. P. (2000). Taxonomy of Antarctic Flavobacterium species: description of Flavobacterium gillisiae sp. nov., Flavobacterium tegetincola sp. nov. and Flavobacterium xanthum sp. nov., nom. rev. and reclassification of [Flavobacterium] salegens as Salegentibacter salegens gen. nov., comb. nov. Int J Syst Evol Microbiol 50, 1055-1063.

Powers, E. M. (1995). Efficacy of the Ryu nonstaining $\mathrm{KOH}$ technique for rapidly determinig Gram reactions of food-borne and waterborne bacteria and yeasts. Appl Environ Microbiol 61, 3756-3758.

Raguénès, G., Christen, R., Guézennec, J., Pignet, P. \& Barbier, G. (1997). Vibrio diabolicus sp. nov., a new polysaccharide-secreting organism isolated from a deep-sea hydrothermal vent polychaete annelid, Alvinella pompejana. Int J Syst Bacteriol 47, 989-995.

Sako, Y., Takai, K., Ishida, Y., Uchida, A. \& Katayama, Y. (1996). Rhodothermus obamensis sp. nov., a modern lineage of extremely thermophilic marine bacteria. Int J Syst Bacteriol 46, 1099-1104.

Stoecker, K., Bendinger, B., Schöning, B., Nielsen, P. H., Nielsen, J. L., Baranyi, C., Toenshoff, E. R., Daims, H. \& Wagner, M. (2006). Cohn's Crenothrix is a filamentous methane oxidizer with an unusual methane monooxygenase. Proc Natl Acad Sci U S A 103, 2363-2367.

Tang, Y. W., Ellis, N. M., Hopkins, M. K., Smith, D. H., Dodge, D. E. \& Persing, D. H. (1998). Comparison of phenotypic and genotypic 
techniques for identification of unusual aerobic pathogenic gramnegative bacilli. J Clin Microbiol 36, 3674-3679.

Urios, L., Agogue, H., Lesongeur, F., Stackebrandt, E. \& Lebaron, P.

(2006). Balneola vulgaris gen. nov., sp. nov., a member of the phylum Bacteroidetes from the north-western Mediterranean Sea. Int J Syst Evol Microbiol 56, 1883-1887.

Wery, N., Lesongeur, F., Pignet, P., Derennes, V., Cambon-Bonavita, M., Godfroy, A. \& Barbier, G. (2001a). Marinitoga camini gen. nov., sp. nov., a rod-shaped bacterium belonging to the order Thermotogales, isolated from a deep-sea hydrothermal vent. Int J Syst Evol Microbiol 51, 495-504.

Wery, N., Moricet, J., Cueff, V., Jean, J., Pignet, P., Lesongeur, F., Cambon-Bonavita, M. \& Barbier, G. (2001b). Caloranaerobacter azorensis gen. nov., sp. nov., an anaerobic thermophilic bacterium isolated from a deep-sea hydrothermal vent. Int J Syst Evol Microbiol 51, 1789-1796. 